\title{
The cost of feeding bred dairy heifers on native warm-season grasses and harvested feedstuffs
}

\author{
J. K. Lowe II, ${ }^{*}$ C. N. Boyer, ${ }^{* 1}$ A. P. Griffith, ${ }^{*}$ J. C. Waller,† G. E. Bates,† P. D. Keyser,§ J. A. Larson, ${ }^{*}$ \\ and E. Holcomb§ \\ *Department of Agricultural and Resource Economics, \\ †Department of Animal Science, \\ fDepartment of Plant Sciences, and \\ §Department of Forestry, Wildlife and Fisheries, The University of Tennessee, Knoxville 37996
}

\begin{abstract}
Heifer rearing is one of the largest production expenses for dairy cattle operations, which is one reason milking operations outsource heifer rearing to custom developers. The cost of harvested feedstuffs is a major expense in heifer rearing. A possible way to lower feed costs is to graze dairy heifers, but little research exists on this topic in the mid-south United States. The objectives of this research were to determine the cost of feeding bred dairy heifers grazing native warm-season grasses (NWSG), with and without legumes, and compare the cost of grazing with the cost of rearing heifers using 3 traditional rations. The 3 rations were corn silage with soybean meal, corn silage with dry distillers grain, and a wet distillers grain-based ration. Bred Holstein heifers between 15- and 20-mo-old continuously grazed switchgrass (SG), SG with red clover $(\mathrm{SG}+\mathrm{RC})$, a big bluestem and Indiangrass mixture (BBIG), and BBIG with red clover (BBIG+RC) in Tennessee during the summer months. Total grazing days were calculated for each NWSG to determine the average cost/animal per grazing day. The average daily gain (ADG) was calculated for each NWSG to develop 3 harvested feed rations that would result in the same ADG over the same number of grazing day as each NWSG treatment. The average cost/animal per grazing day was lowest for SG (\$0.48/animal/grazing d) and highest for BBIG+RC (\$1.10/animal/grazing d). For both BBIG and SG, legumes increased the average cost/animal per grazing day because grazing days did not increase enough to account for the additional cost of the legumes. No difference was observed in ADG for heifers grazing BBIG $(0.85 \mathrm{~kg} / \mathrm{d})$ and BBIG+RC $(0.94 \mathrm{~kg} / \mathrm{d})$, and no difference was observed in ADG for heifers grazing SG (0.71 $\mathrm{kg} / \mathrm{d})$ and $\mathrm{SG}+\mathrm{RC}(0.70 \mathrm{~kg} / \mathrm{d})$. However, the ADG
\end{abstract}

Received February 16, 2015.

Accepted September 6, 2015.

${ }^{1}$ Corresponding author: Cboyer3@utk.edu for heifers grazing $\mathrm{SG}$ and $\mathrm{SG}+\mathrm{RC}$ was lower than the ADG for heifers grazing either BBIG or BBIG+RC. The average cost/animal per grazing day was lower for all NWSG treatments than the average cost/animal per day for all comparable feed rations at a low, average, and high yardage fee. Results of this study suggest that SG was the most cost-effective NWSG alternative to harvested feeds for bred dairy heifer rearing.

Key words: bred dairy heifer, economics, grazing, native warm-season grass, Tennessee

\section{INTRODUCTION}

For a dairy operation, heifer rearing can be one of the largest annual production expenses (Heinrichs, 1993; Harsh et al., 2001). Feed costs can account for as much as $64 \%$ of the total cost of heifer production (Gabler et al., 2000). Harvested feedstuffs such as corn (Zea mays) silage have been the primary feedstuffs used in dairy heifer rations. However, the cost of heifer rearing relying on harvested feedstuffs has increased due to increased cost of producing crops such as corn (Griffith, 2012; USDA-NASS, 2013).

A profit-maximizing dairy heifer producer's objective is to reduce production costs while holding output constant. One possible way to lower the cost of bred heifer rearing is to graze heifers. In the mid-south United States, tall fescue (TF) [Schedonorus arundinaceus (Schreb.) Dumort] is the primary forage cattle producers rely on for pasture and hay (Keyser et al., 2011). However, interest is growing by cattle producers in grazing native warm-season grasses (NWSG) during the summer months because of their drought tolerance.

Research on dairy heifer rearing while grazing NWSG has been limited. Eastern gamagrass (Tripsacum dactyloides) was used as an additive to corn silage and alfalfa (Medicago sativa) haylage in Wisconsin and was found to dilute energy content and limit DMI (Coblentz et al., 2012). Coblentz et al. (2012) stated more research was needed on the animal benefits from using NWSG 
in rearing dairy heifers. Furthermore, in our review of literature, no studies were found on the cost of grazing NWSG in the rearing of bred dairy heifers.

Research is limited on grazing NWSG with legumes in the mid-south United States. A potential shortcoming of a NWSG summer grazing program can be the cost of $\mathrm{N}$ fertilizer applied (Doxon et al., 2011; Biermacher et al., 2012). Legumes can replace inorganic $\mathrm{N}$ (Howieson et al., 2000) and can be successfully grown with switchgrass (SG; Panicum virgatum L.; Blantchet et al., 1995); however, legumes have also been found to weaken SG stand through excessive spring competition (Bow et al., 2008). Biermacher et al. (2012) studied the economics of using legumes as a substitute for $\mathrm{N}$ fertilizer while grazing bermudagrass (Cynodon dactylon) pastures in the Great Plains, and found net returns to grazing to be higher for the pastures where $\mathrm{N}$ fertilizer was applied than the pastures where legumes were seeded. However, more research is needed on the economics of grazing NWSG with legumes.

The objective of this research was to determine the cost of grazing bred dairy heifers on SG and a big bluestem (Andropogon gerardii) and Indiangrass (Sorghastrum nutans) mixture (BBIG) with and without legumes. The results from this research could benefit dairy heifer producers in the mid-south and other regions where NWSG are grown by reducing feed costs in the summer months.

\section{MATERIALS AND METHODS}

\section{Data}

Animal and Pasture Management. Data were collected from an experiment conducted at the Middle Tennessee Research and Education Center in Spring Hill, Tennessee, from 2010 to 2012. Animal performance data were collected for bred Holstein and Jersey heifers grazing mature stands of 4 NWSG treatments: (1) SG, (2) BBIG, (3) SG with red clover (Trifolium pretense; $\mathbf{S G}+\mathbf{R C}$ ), and (4) BBIG with red clover $(\mathbf{B B I G}+\mathbf{R C})$. Table 1 presents rainfall and temperature data collected at the Middle Tennessee Research and Education Center from 2010 to 2012. Treatments were assigned in a randomized complete block design with 4 replications. A total of 16 paddocks were used in each year of the study. Each NWSG treatment was established in 2008 on 1.2-ha paddocks by no-till drill at seeding rates of $7.9 \mathrm{~kg}$ of pure live seed (PLS)/ ha for Alamo SG, and a 2:1 mixture of big bluestem and Indiangrass was seeded at $11.2 \mathrm{~kg}$ of PLS/ha. Cinnamon Plus clover was drilled in February of each year in pastures assigned to the legume treatments at a rate
Table 1. Average daily temperature $\left({ }^{\circ} \mathrm{C}\right)$ and total rainfall $(\mathrm{cm})$ during native warm-season grass grazing months in Spring Hill, Tennessee, from 2010 to $2012^{1}$

\begin{tabular}{lcc}
\hline & \multicolumn{2}{c}{ Average } \\
\cline { 2 - 3 } Month & Temperature & Rainfall \\
\hline May & $19.76(1.45)$ & $18.04(14.67)$ \\
June & $24.62(1.71)$ & $6.80(3.54)$ \\
July & $26.89(0.28)$ & $12.61(9.80)$ \\
August & $25.39(1.80)$ & $7.07(3.54)$ \\
May to August & $24.17(0.91)$ & $44.81(16.19)$ \\
\hline
\end{tabular}

${ }^{1}$ Source: NOAA, Spring Hill, Tennessee, weather station. Standard deviations are shown in parentheses.

of $5.6 \mathrm{~kg}$ of PLS/ha. In the fall of each year, all paddocks were clipped to remove excess forage. No lime, fertilizer, or herbicides were applied to the treatments in any year.

Animals were managed in a continuous grazing system with a variable stocking rate beginning in mid-May. Grazing was initiated each year when forage height reached approximately $38.1 \mathrm{~cm}$. Grazing was initiated on May 14, 2010, May 13, 2011, and May 11, 2012. Each paddock contained 4 tester animals with a variable amount of grazer animals dependent on the forage availability of the NWSG. Testers were animals used to evaluate the paddock quality and animal performance while grazer animals were used to maintain the target height for each NWSG (Mott, 1960). When forage growth was over the target height, grazers were added to the paddock and when forage growth was within the desired range, grazers were removed. The goal was to maintain a plant height of 38.1 to $45.72 \mathrm{~cm}$ for BBIG and 60.96 to $76.2 \mathrm{~cm}$ for SG. Although the continuous grazing system with a variable stocking rate was an appropriate method for grazing experiments (Mott, 1960), this method does not represent how producers would actually graze dairy heifers. The data, however, provide controlled measurements on how dairy heifers perform on NWSG.

In 2010 and 2012, 4 bred Holstein heifers were designated as testers and assigned to each paddock. In 2011, 3 bred Holstein heifers and 1 bred Jersey heifer were assigned as tester animals due to a shortage of Holstein heifers. Pregnancy status was 30 to $160 \mathrm{~d}$ for all bred heifers, and age ranged from 15 to 20 mo old for all bred heifers. In 2010 and 2012, all grazers were Holsteins, but both Jerseys and Holsteins were used in 2011. The initial stocking rate was 4 testers per paddock in 2010 and 2012 for all NWSG treatments, but in 2011 the initial stocking rate was 4 testers and 1 grazer for BBIG paddocks, and 4 testers and 3 grazers for SG paddocks. 
Table 2. Average on-weights $(\mathrm{kg})$, off-weights $(\mathrm{kg})$, grazing days per hectare, CP (\% of DM), ADF, NDF, and ADG $(\mathrm{kg} / \mathrm{d})$ for bred dairy heifers grazing native warm-season grasses (NWSG) at Spring Hill, Tennessee, from 2010 to $2012^{1}$

\begin{tabular}{lcccc}
\hline & \multicolumn{4}{c}{ NWSG } \\
\cline { 2 - 5 } Item & BBIG & BBIG+RC & SG & SG+RC \\
\hline Average on-weight, Holstein (kg) & 479.97 & 475.00 & 472.29 & 471.07 \\
& $(63.64)$ & $(65.09)$ & $(57.65)$ & $(55.89)$ \\
Average off-weight, Holstein (kg) & 536.54 & 535.65 & 522.75 & 521.25 \\
& $(61.35)$ & $(63.64)$ & $(52.82)$ & $(54.30)$ \\
Average on-weight, Jersey (kg) & 325.68 & 352.21 & 362.64 & 348.96 \\
& $(34.61)$ & $(17.34)$ & $(23.64)$ & $(17.78)$ \\
Average off-weight, Jersey (kg) & 381.47 & 409.13 & 402.11 & 384.34 \\
& $(31.90)$ & $(23.55)$ & $(21.78)$ & $(21.12)$ \\
Average grazing days (d/ha) & 222.12 & 222.52 & 280.05 & 292.2 \\
& $(69.23)$ & $(69.26)$ & $(51.24)$ & $(61.34)$ \\
Average CP (\% of DM) & 8.00 & 9.34 & 7.01 & 7.23 \\
& $(0.75)$ & $(0.74)$ & $(0.75)$ & $(0.75)$ \\
Average ADF & 47.46 & 45.92 & 47.20 & 45.81 \\
& $(1.13)$ & $(1.14)$ & $(1.13)$ & $(1.13)$ \\
Average NDF & 77.25 & 74.00 & 76.40 & 75.51 \\
ADG ${ }^{2}$ (kg/d) & $(1.70)$ & $(1.71)$ & $(1.69)$ & $(1.70)$ \\
& $\left(0.85^{\mathrm{b}}\right.$ & $0.94^{\mathrm{b}}$ & $0.71^{\mathrm{a}}$ & $0.70^{\mathrm{a}}$ \\
& $(0.19)$ & $(0.14)$ & $(0.10)$ & $(0.16)$ \\
\hline
\end{tabular}

a,b Means within a row with different superscripts differ $(P<0.05)$.

${ }^{1}$ Native warm-season grass (NWSG) treatments: BBIG = big bluestem and Indiangrass; $\mathrm{BBIG}+\mathrm{RC}=\mathrm{big}$ bluestem and Indiangrass with legumes; SG = switchgrass; SG+RC = switchgrass with legumes. Standard error of the mean is reported in parentheses.

${ }^{2}$ Least squares means average cost/grazing day.

Heifers were placed on a high fiber equilibration diet before and after entering the paddocks. This diet was used to regulate gut fill without adding weight to the animals, allowing for a more accurate measurement of gain than traditional methods such as averaging weights from multiple days. Testers were fed an equilibration ration at $2.0 \%$ of $\mathrm{BW}$ for $5 \mathrm{~d}$ before entering and $5 \mathrm{~d}$ after leaving the experiment. On a DM basis, the ration was $12.9 \% \mathrm{CP}$ and $27.2 \%$ crude fiber; it was composed of cottonseed hulls, soy hull pellets, citrus pulp, dried distillers grain, and molasses. The last $2 \mathrm{~d}$ of the 5 - $\mathrm{d}$ high-fiber equilibration diet before grazing were averaged to calculate an average on-weight, and the last $2 \mathrm{~d}$ of the 5-d high-fiber equilibration diet postgrazing were averaged to calculate the off-weight. The average onweights and off-weights for bred dairy heifers by breed, year, and NWSG are presented in Table 2.

On both dates heifers were weighed, forage samples for yield and quality were taken from each NWSG treatment. All samples were scanned using a nearinfrared reflectance spectrophotometer to determine nutrient levels. Average CP, ADF, and NDF levels by NWSG and year are presented in Table 2. In 2012, CP levels increased for all NWSG, which was likely due to weather conditions and changes in establishment of the clover. Decisions on termination of grazing were based upon animal performance, pasture conditions, or both. Termination dates were August 9, 2010, July 22, 2011, and June 29, 2012, for the BBIG treatments, and termination dates for SG were August 9, 2010, July 22, 2011, and July 13, 2012, for the SG pastures. In 2012, Holstein heifers grazing BBIG paddocks were removed from grass 2 wk earlier than the heifers on the SG paddocks. This removal was based on the NWSG availability, which was dependent on rainfall and temperature. The total grazing days for each paddock included all animals, testers, and grazers on that paddock at any point during the grazing period. For each paddock, number of animals/grazing day per hectare were calculated by dividing number of animals by the total grazing days by the number of hectares/paddock (Table 2).

Feed Ration Development. The feed rations were developed to achieve the same ADG over the same number of days as one of the NWSG treatments, giving a total of 12 rations. The ingredients for each ration were determined based on the Cattle Grower Ration Balancing Spreadsheet (University of Arkansas Division of Agriculture, 2006) for a Holstein heifer that has the same beginning weight as the average beginning weight of those in the grazing experiment. The 3 rations were corn silage with soybean meal, corn silage with dry distillers grain, and a wet distillers grain-based ration (Table 3). Moisture level of the rations, nutritional 
value on a DM basis, and the as-fed feed-to-gain ratio associated with each ration were also calculated (Table $3)$.

The average cost of the feedstuff inputs from 2009 to 2012 over the summer grazing months were used to determine ration costs in 2012 dollars. The price of wet distillers grain (65-70\% moisture) was $\$ 63 / \mathrm{Mg}$ and dry distillers grain (10\% moisture) was $\$ 193 / \mathrm{Mg}$ (USDA, 2013). The price of corn silage was $\$ 55 / \mathrm{Mg}$, which was estimated using historical corn yields and prices for Tennessee (USDA-NASS, 2013) along with the Corn Silage Crop Calculator. The average price of hay was $\$ 94 / \mathrm{Mg}$ from a non-alfalfa hay market in Kentucky (USDA-NASS, 2013). Kentucky hay prices were used because Kentucky was the nearest hay market to Tennessee that has price data available by year and month. Marketing year prices of soybean meal were used to establish the price of $\$ 679 / \mathrm{Mg}$ because monthly prices were unavailable (USDA-NASS, 2013). Due to a lack of historical prices of calcium carbonate, the local price of $\$ 88 / \mathrm{Mg}$ was used in calculating the cost of each ration. The yardage fees evaluated were $\$ 0.35$, $\$ 0.40$, and $\$ 0.45 /$ animal per $\mathrm{d}$, which were intended to represent a low, medium, and high daily yardage fee within the range generally charged by custom feeders (Lardy, 2013). During the time of the study, the price of feedstuffs was historically high; therefore, a sensitivity analysis was conducted when all feedstuff prices were assumed to be $50 \%$ lower.

Budgeting. Enterprise budgets were used to estimate establishment, operational, and legume costs for grazing $\mathrm{BBIG}, \mathrm{BBIG}+\mathrm{RC}, \mathrm{SG}$, and $\mathrm{SG}+\mathrm{RC}$. A 10-yr production horizon was assumed, with no grazing occurring in the establishment year (Duffy, 2007; Khanna et al., 2008; Haque et al., 2009; Mooney et al., 2009; Griffith et al., 2011; Boyer et al., 2013; Lowe et al., 2015). In the establishment year, a seedbed was prepared for no-till planting by spraying the paddocks and seed was planted. As stated before, NWSG can be difficult to establish and sometimes requires reestablishment; thus, a 10\% chance of failed establishment was assumed to account for the potential cost of reestablishment in the

Table 3. Theoretical nutrient requirements for formulated rations to achieve similar growth rates in bred Holstein heifers as measured on native warm-season grasses (NWSG) on an as-fed diet composition $(\%)^{1}$

\begin{tabular}{|c|c|c|c|c|}
\hline \multirow[b]{2}{*}{ Ration $^{2}$} & \multicolumn{4}{|c|}{ NWSG treatment } \\
\hline & BBIG & $\mathrm{BBIG}+\mathrm{RC}$ & SG & $\mathrm{SG}+\mathrm{RC}$ \\
\hline \multicolumn{5}{|l|}{ Wet distillers grain } \\
\hline Wet distillers grain (\%) & 60.75 & 65.50 & 49.50 & 49.50 \\
\hline Mixed grass hay (\%) & 38.25 & 33.50 & 49.50 & 49.50 \\
\hline Calcium carbonate $(\%)$ & 1.00 & 1.00 & 1.00 & 1.00 \\
\hline Feed:gain ${ }^{3}$ & 27.36 & 24.75 & 29.10 & 29.28 \\
\hline $\mathrm{DM}^{4}(\%)$ & 49.70 & 46.70 & 56.70 & 56.70 \\
\hline $\operatorname{TDN}^{5}(\%)$ & 63.20 & 65.10 & 60.10 & 60.10 \\
\hline $\mathrm{CP}^{6}(\%)$ & 15.40 & 16.10 & 14.20 & 14.20 \\
\hline \multicolumn{5}{|l|}{ Corn silage-soybean meal } \\
\hline Corn silage $(\%)$ & 71.00 & 78.50 & 50.00 & 50.00 \\
\hline Mixed grass hay (\%) & 22.00 & 14.50 & 42.00 & 42.00 \\
\hline Soybean meal $(\%)$ & 7.00 & 7.00 & 8.00 & 8.00 \\
\hline Feed:gain ${ }^{3}$ & 27.81 & 27.46 & 27.48 & 27.48 \\
\hline $\mathrm{DM}^{4}(\%)$ & 48.90 & 44.80 & 60.40 & 60.40 \\
\hline $\operatorname{TDN}^{5}(\%)$ & 63.10 & 64.80 & 60.10 & 60.10 \\
\hline $\mathrm{CP}^{6}(\%)$ & 15.10 & 15.40 & 15.20 & 15.20 \\
\hline \multicolumn{5}{|c|}{ Corn silage-dry distillers grain } \\
\hline Corn silage $(\%)$ & 44.50 & 54.50 & 21.00 & 21.00 \\
\hline Mixed grass hay (\%) & 40.50 & 30.50 & 64.00 & 64.00 \\
\hline Dry distillers grain (\%) & 15.00 & 15.00 & 15.00 & 15.00 \\
\hline Feed:gain ${ }^{3}$ & 21.32 & 20.89 & 21.67 & 21.67 \\
\hline $\mathrm{DM}^{4}(\%)$ & 63.80 & 58.40 & 76.60 & 76.60 \\
\hline $\operatorname{TDN}^{5}(\%)$ & 63.40 & 65.10 & 60.30 & 60.30 \\
\hline $\mathrm{CP}^{6}(\%)$ & 14.80 & 15.00 & 14.40 & 14.40 \\
\hline \multicolumn{5}{|c|}{$\begin{array}{l}{ }_{1}^{1} \mathrm{BBIG}=\text { big bluestem and Indiangrass; } \mathrm{BBIG}+\mathrm{RC}=\text { big bluestem and Indiangrass with legumes; SG } \\
\text { switchgrass: } \mathrm{SG}+\mathrm{RC}=\text { switch grass with legumes. }\end{array}$} \\
\hline \multicolumn{5}{|c|}{${ }^{2}$ Includes the data from the Holsteins and Jerseys used in this study. } \\
\hline \multicolumn{5}{|c|}{${ }^{3}$ Ratio of ration fed to gain achieved $(\mathrm{kg})$ on an as-fed basis. } \\
\hline \multicolumn{5}{|l|}{${ }^{4}$ Percent $\mathrm{DM}$ of ration. } \\
\hline \multicolumn{5}{|c|}{${ }^{5}$ Percentage total digestible nutrients (TDN) on a DM basis. } \\
\hline
\end{tabular}


Table 4. Total establishment and annualized pasture costs (\$/ha) for each native warm-season grass (NWSG) in 2012 dollars $^{1}$

\begin{tabular}{|c|c|c|c|c|}
\hline Total pasture cost & BBIG & $\mathrm{BBIG}+\mathrm{RC}$ & SG & $\mathrm{SG}+\mathrm{RC}$ \\
\hline \multicolumn{5}{|l|}{ Establishment cost } \\
\hline NWSG seed ${ }^{2}$ & 417.17 & 417.17 & 192.51 & 192.51 \\
\hline Establishment $^{3}$ & 208.17 & 208.17 & 208.17 & 208.17 \\
\hline Risk of re-establishment ${ }^{4}$ & 62.53 & 62.53 & 40.07 & 40.07 \\
\hline Total establishment cost & 687.87 & 687.87 & 440.75 & 440.75 \\
\hline Annualized establishment & 91.26 & 91.26 & 58.47 & 58.47 \\
\hline \multicolumn{5}{|l|}{ Legume cost } \\
\hline Seed & - & 81.51 & - & 81.51 \\
\hline Machinery and labor & - & 31.41 & - & 31.41 \\
\hline \multicolumn{5}{|l|}{ Operational cost } \\
\hline Mowing & 21.04 & 21.04 & 21.04 & 21.04 \\
\hline Land rent & 51.87 & 51.87 & 51.87 & 51.87 \\
\hline Total annual pasture cost & 164.17 & 277.09 & 131.38 & 244.31 \\
\hline
\end{tabular}

following year. An annual discount rate of $5.5 \%$ was calculated using a 10-yr average annual inflation rate of $2.5 \%$ for the 2003-2012 (US Department of Labor, 2013) and subtracting it from the nominal annual interest rate of $8 \%$ used in the University of Tennessee Department of Agricultural Economics (2009).

Total establishment and production costs of NWSG were calculated following the University of Tennessee Department of Agricultural Economics (2009) and Doxon et al. (2011; Table 4). The establishment costs included seed, herbicide, machinery, and labor. An average of local prices in 2012 was used to determine seed costs of $\$ 36.72 / \mathrm{kg}$ for big bluestem, $\$ 50.05 / \mathrm{kg}$ for Indiangrass, and $\$ 28.58 / \mathrm{kg}$ for SG. The total establishment cost was annualized and added to the annual operational costs of land rent and legume costs to calculate total annual cost of production over a 10-year useful pasture life. Legume establishment cost was estimated using the University of Tennessee Department of Agricultural Economics (2007), which included seed, machinery, and labor. Clover was seeded each year in the study, so this cost was included on an annual basis.

\section{Economics Framework}

Cost of Grazing. For the framework of this research, the assumption was made that dairy heifer growers were paid on a dollar/animal per day basis to rear a heifer because this is how the majority of contracts are structured (Wolf, 2003; Olynk and Wolf, 2010). It was assumed dairy producers operate in a perfectly competitive market for inputs and outputs, where the end product was a dairy heifer 7 mo bred and meeting all contractual obligations. Once the heifer was bred, every heifer was worth the same dollar value, meaning the producer was a price taker and had no influence on the price they received. Therefore, a risk neutral, profitmaximizing dairy grower would need to minimize their cost of producing a heifer from the time of breeding until the heifer was a few weeks from delivering a calf to achieve the largest average economic profit. In this study, a profit-maximizing, risk-neutral producer would select the NWSG treatment that maximizes profits by minimizing the average cost/animal per day.

To find the average cost/animal per day for grazing the NWSG, the annual pasture cost/hectare was divided by the number of animal/grazing day per hectare for each treatment. The annualized establishment cost (\$/ha) included the cost of seed, land rent, herbicide, and machinery. This cost was added to the annual operational costs $(\$ / \mathrm{ha})$, land rent $(\$ / \mathrm{ha})$, and the cost of annual legume seeding $(\$ /$ ha $)$ to find the total annual pasture cost $(\$ /$ ha). Because no fertilizer was used in this experiment, the cost of fertilizer was not included in establishment and the annual pasture costs.

Feed Ration Cost. The average cost/animal per day of grazing the NWSG was then compared with the average cost/animal per day using harvested feedstuff rations. Three rations were developed using harvested feedstuffs common to Tennessee to achieve animal performance equivalent to each of the NWSG treatments over the same time period. The 3 types of feed rations were a wet distillers grain-based ration, a corn silage with soybean meal ration, and a corn silage with dried 
distillers grain ration. Because 3 rations were used for each of the 4 NWSG treatments, a total of 12 rations were developed. These are common rations used in dairy heifer rearing (Coblentz et al., 2012) and in the mid-south (Griffith, 2012). To accurately compare the average cost/animal per grazing day for each NWSG to the average cost/animal per day of using harvested feed rations, a composition of ingredients was formulated for each ration to achieve the same theoretical ADG over the same number of grazing day for the same size heifer as each NWSG treatment. Then, the average cost of the feed ration was calculated by multiplying the cost of the ingredients by the quantity needed of each ingredient to achieve an equivalent ADG over the same time period as each NWSG treatment. First, the average cost per kilogram of the feed ration was calculated as

$$
\mathrm{E}\left(\mathrm{FC}_{j}\right)=\sum_{k=1}^{K} \phi_{j k} \mathrm{I}_{j k},
$$

where $\mathrm{E}\left(\mathrm{FC}_{j}\right)$ is the average feed cost $/ \mathrm{kg}$ of ration $j(j$ $=1, \ldots, 12) ; \phi_{j k}$ is the percentage of the $k$ th $(k=1$, $\ldots, K)$ ingredient for the $j$ th feed ration; and $\mathrm{I}_{j k}$ is the ingredient cost $(\$ / \mathrm{kg})$ for the $k$ th ingredient in the $j$ th feed ration. Then, the average cost $/ \mathrm{kg}$ of gain on the harvested feed was calculated as

$$
\mathrm{E}\left(\mathrm{C}_{j}\right)=\mathrm{E}\left(\mathrm{FC}_{j} \times \mathrm{FG}_{j}\right),
$$

where $\mathrm{E}\left(\mathrm{C}_{j}\right)$ is the producer's average cost $/ \mathrm{kg}$ of gain for the $j$ th feed ration; and $\mathrm{FG}_{j}$ is the average feed to gain ratio on an as-fed basis for the $j$ th feed ration, which is the amount of feed required to achieve $1 \mathrm{~kg}$ of gain.

The average cost/animal per day using harvested feed was determined by multiplying ADG by the average cost for $1 \mathrm{~kg}$ of gain, which was expressed as

$$
\mathrm{E}\left(\mathrm{CF}_{j i}\right)=\mathrm{E}\left(\mathrm{ADG}_{i} \times \mathrm{C}_{j}\right)+\mathrm{YT},
$$

where $\mathrm{CF}_{j i}$ is the producer's average cost/animal per day for the $j$ th feed ration under the $i$ th NWSG treatment; $\mathrm{ADG}_{i}$ is the average daily gain for the $i$ th NWSG treatment that the feed ration was designed to match; and $\mathrm{YT}$ is the yardage and transportation fees that were evaluated.

\section{Statistical Methods}

A mixed model ANOVA was used to compare the fixed effects of each NWSG treatment on the average cost/animal per grazing day and ADG. A random effect was included to account for year-to-year variability such as stochastic weather events. The null hypotheses were that the average cost/animal per grazing day was not different across NWSG treatments and that ADG was not different across NWSG treatments. The MIXED procedure in SAS 9.2 was used to estimate these models, and the PDIFF function of LSMEANS was used to evaluate means (SAS Institute Inc., Cary, NC). Significance was determined at $P \leq 0.05$.

\section{RESULTS AND DISCUSSION}

Table 2 presents the ADG for heifers grazing each NWSG treatment. It is recommended the ADG of Holstein heifers be 0.79 to $0.91 \mathrm{~kg} / \mathrm{d}$ from weaning to calving, whereas smaller breed heifers such as Jerseys should have an ADG near $0.59 \mathrm{~kg} / \mathrm{d}$ before calving (Hopkins and Whitlow, 2001; Zanton and Heinrichs, 2007; Zanton and Heinrichs, 2008). The ADG of 0.94 $\mathrm{kg} / \mathrm{d}$ for heifers grazing BBIG+RC was not different $(P \leq 0.05)$ from those grazing BBIG $(0.85 \mathrm{~kg} / \mathrm{d})$ and was on the upper end of ADG recommendations for dairy heifers (Zanton and Heinrichs, 2008). Similarly, no difference was found in ADG for animals grazing SG $(0.71 \mathrm{~kg} / \mathrm{d})$ and $\mathrm{SG}+\mathrm{RC}(0.70 \mathrm{~kg} / \mathrm{d})$. In North Carolina, Burns (2011) studied beef steers on big bluestem and SG and projected gains would range from 0.7 to 0.9 $\mathrm{kg} / \mathrm{d}$, which is similar to gains experienced in this study for bred dairy heifers. Additionally, Burns et al. (2011) studied beef steer performance on SG and found ADG in the early grazing period to be 1.11 and $0.33 \mathrm{~kg} / \mathrm{d}$ for late period grazing. Similarly, Lowe et al. (2015) determined the ADG for beef steers over a 90-d grazing period in the summer had an ADG of $0.56 \mathrm{~kg} / \mathrm{d}$ for $\mathrm{SG}$ and $0.82 \mathrm{~kg} / \mathrm{d}$ for BBIG.

The ADG for heifers grazing $\mathrm{SG}$ and $\mathrm{SG}+\mathrm{RC}$ was lower $(P \leq 0.05)$ than the ADG for heifers grazing $\mathrm{BBIG}$ or BBIG+RC. On average, heifers grazing BBIG gained $0.14 \mathrm{~kg} / \mathrm{d}$ more than heifers on $\mathrm{SG}$ and 0.15 $\mathrm{kg} / \mathrm{d}$ more than heifers on $\mathrm{SG}+\mathrm{RC}$. The ADG for heifers on $\mathrm{BBIG}+\mathrm{RC}$ was $0.23 \mathrm{~kg} / \mathrm{d}$ higher than heifers grazing $\mathrm{SG}$ and $0.24 \mathrm{~kg} / \mathrm{d}$ higher than heifers grazing $\mathrm{SG}+\mathrm{RC}$.

The ADG on SG and SG+RC was likely lower than $\mathrm{BBIG}$ and $\mathrm{BBIG}+\mathrm{RC}$ because $\mathrm{SG}$ matures earlier in the year than BBIG (Keyser et al., 2011). Earlier maturation likely led to lower quality forage through the duration of the grazing period relative to BBIG treatments and thus resulted in lower ADG. Concerns could be possible about the ADG experienced when grazing $\mathrm{SG}$ and $\mathrm{SG}+\mathrm{RC}$ because ADG were slightly below the range in which prior research has found to 
Table 5. Average cost/animal per day and sensitivity analysis for heifers consuming distillers grain and corn silage-based rations to achieve the same animal performance as grazing the native warm-season grass (NWSG) treatments at Spring Hill, Tennessee, from 2010 to 2012

\begin{tabular}{|c|c|c|c|c|}
\hline Ration $^{1}$ & $\mathrm{BBIG}^{2}$ & $\mathrm{BBIG}+\mathrm{RC}^{2}$ & $\mathrm{SG}^{2}$ & $\mathrm{SG}+\mathrm{RC}^{2}$ \\
\hline \multicolumn{5}{|l|}{ Wet distillers grain } \\
\hline Cost of gain $(\$ / \mathrm{kg})$ & 2.03 & 1.81 & 2.28 & $\$ 2.29$ \\
\hline Yardage low ${ }^{3}(\$ /$ animal $/ \mathrm{d})$ & 2.08 & 2.05 & 1.97 & $\$ 1.95$ \\
\hline Yardage average (\$/animal/d) & 2.13 & 2.10 & 2.02 & $\$ 2.00$ \\
\hline Yardage high (\$/animal/d) & 2.18 & 2.15 & 2.07 & $\$ 2.05$ \\
\hline \multicolumn{5}{|l|}{ Sensitivity analysis ${ }^{4}$} \\
\hline Cost of gain $(\$ / \mathrm{kg})$ & 1.03 & 0.91 & 1.14 & $\$ 1.15$ \\
\hline Yardage low ${ }^{3}$ (\$/animal/d) & 1.22 & 1.21 & 1.16 & $\$ 1.16$ \\
\hline Yardage average (\$/animal/d) & 1.27 & 1.26 & 1.21 & $\$ 1.21$ \\
\hline Yardage high (\$/animal/d) & 1.32 & 1.31 & 1.26 & $\$ 1.26$ \\
\hline \multicolumn{5}{|l|}{ Corn silage-soybean meal } \\
\hline Cost of gain $(\$ / \mathrm{kg})$ & 2.99 & 2.88 & 3.34 & $\$ 3.34$ \\
\hline Yardage $\operatorname{low}^{3}(\$ /$ animal/d) & 2.89 & 3.06 & 2.72 & $\$ 2.69$ \\
\hline Yardage average (\$/animal/d) & 2.94 & 3.11 & 2.77 & $\$ 2.74$ \\
\hline Yardage high (\$/animal/d) & 2.99 & 3.16 & 2.82 & $\$ 2.79$ \\
\hline \multicolumn{5}{|l|}{ Sensitivity analysis ${ }^{4}$} \\
\hline Cost of gain $(\$ / \mathrm{kg})$ & 1.49 & 1.43 & 1.67 & $\$ 1.67$ \\
\hline Yardage low ${ }^{3}$ (\$/animal/d) & 1.62 & 1.70 & 1.53 & $\$ 1.52$ \\
\hline Yardage average (\$/animal/d) & 1.67 & 1.75 & 1.58 & $\$ 1.57$ \\
\hline Yardage high (\$/animal/d) & 1.72 & 1.80 & 1.63 & $\$ 1.62$ \\
\hline \multicolumn{5}{|l|}{ Corn silage-dry distillers } \\
\hline Cost of gain $(\$ / \mathrm{kg})$ & 1.96 & 1.83 & 2.19 & $\$ 2.19$ \\
\hline Yardage $\operatorname{low}^{3}(\$ /$ animal/d) & 2.02 & 2.07 & 1.91 & $\$ 1.89$ \\
\hline Yardage average $(\$ /$ animal/d) & 2.07 & 2.12 & 1.96 & $\$ 1.94$ \\
\hline Yardage high (\$/animal/d) & 2.12 & 2.17 & 2.01 & $\$ 1.99$ \\
\hline \multicolumn{5}{|l|}{ Sensitivity analysis ${ }^{4}$} \\
\hline Cost of gain $(\$ / \mathrm{kg})$ & 0.98 & 0.91 & 1.09 & $\$ 1.09$ \\
\hline Yardage $\operatorname{low}^{3}(\$ /$ animal/d) & 1.18 & 1.21 & 1.12 & $\$ 1.11$ \\
\hline Yardage average $(\$ /$ animal/d) & 1.23 & 1.26 & 1.17 & $\$ 1.16$ \\
\hline \multirow{3}{*}{ Grazing cost ${ }^{5}$ (\$/animal/grazing d) } & 1.28 & 1.31 & 1.22 & $\$ 1.21$ \\
\hline & $\$ 0.79^{\mathrm{b}}$ & $1.10^{\mathrm{c}}$ & $0.48^{\mathrm{a}}$ & $0.86^{\mathrm{b}}$ \\
\hline & $(0.05)^{6}$ & $(0.05)$ & $(0.05)$ & $(0.05)$ \\
\hline
\end{tabular}

${ }_{\mathrm{a}, \mathrm{b}}$ Means within a row with different superscripts differ $(P<0.05)$.

${ }^{1}$ The average daily gain assumed in each ration was $0.85,0.94,0.71$, and $0.70 \mathrm{~kg} / \mathrm{d}$ for BBIG, BBIG+RC, SG, and $\mathrm{SG}+\mathrm{RC}$, respectively.

${ }^{2} \mathrm{BBIG}=$ big bluestem and Indiangrass; $\mathrm{BBIG}+\mathrm{RC}=$ big bluestem and Indiangrass with legumes; $\mathrm{SG}=$ switchgrass; $\mathrm{SG}+\mathrm{RC}=$ switchgrass with legumes.

${ }^{3}$ Yardage fees were $\$ 0.35, \$ 0.40$, and $\$ 0.45$ /animal per day for the low, average, and high daily yardage (Lardy, 2013).

${ }^{4}$ Feedstuff prices decreased $50 \%$.

${ }^{5}$ Least squares means average cost/grazing day.

${ }^{6}$ Standard error of the mean is reported in parentheses.

be optimal (Hopkins and Whitlow, 2001; Zanton and Heinrichs, 2007, 2008).

The results for the average cost/animal per grazing day for heifers grazing the NWSG treatment are presented in Table 5 . The average cost/animal per grazing day for grazing bred heifers was $\$ 0.79 /$ animal per grazing day for BBIG, $\$ 1.10 /$ animal per grazing day for $\mathrm{BBIG}+\mathrm{RC}, \$ 0.48$ /animal per grazing day for SG, and $\$ 0.86$ /animal per grazing day for $\mathrm{SG}+\mathrm{RC}$. Overall, the average cost/animal per grazing day for grazing was the lowest $(P \leq 0.05)$ for SG. The profit-maximizing custom heifer rearer would choose to graze SG over other NWSG evaluated in this study because it provides the lowest average cost/animal per grazing day. This was largely explained by SG having a relatively high stocking rate compared with BBIG and BBIG+RC, and lower establishment cost (approximately $\$ 32 /$ ha lower than BBIG and BBIG+RC). Although the cost/animal per grazing day was cheapest for SG, producers rearing dairy heifers should be cautious of the lower ADG and make sure these animals are reaching an acceptable weight and body condition. Thus, the manager of the dairy in which such an animal was returning may prefer heifers to be grazed on BBIG because it provides an ADG within the recommended range of ADG for rearing dairy heifers.

Including legumes with SG and BBIG resulted in the cost/animal per grazing day increasing $\$ 0.38(P \leq 0.05)$ 
and $\$ 0.30(P \leq 0.05)$, respectively. A potential reason for the differences in the average cost/animal per grazing day between legume and nonlegume treatments was the inconsistency in legume establishment from year to year. The additional cost of legume establishment without any consistent increased performance resulted in a higher average cost/animal per grazing day for $\mathrm{SG}+\mathrm{RC}$ than $\mathrm{SG}$, and for BBIG+RC than BBIG. Although research has found that legumes can be successfully established in SG (Blantchet et al., 1995), in this study legumes were difficult to establish in stands of SG and BBIG.

The successful establishment of legumes could provide extra protein to animals grazing pasture (Poppi and McLennan, 1995). The increased protein could potentially increase ADG when forage quality was decreasing in SG relative to BBIG. However, the strategy of including legumes may not be as effective in increasing protein supply because of protein degradation in the rumen and a lack of microbes to absorb $\mathrm{NH}_{3}$ (Poppi and McLennan, 1995). Additionally, $\mathrm{N}$ fertilizer could be added to the pastures instead of legumes to increase forage yield and CP. Gillen and Berg (1998) found the application of $35 \mathrm{~kg} / \mathrm{ha}$ of $\mathrm{N}$ on native grass mixtures increased forage mass $60 \%$ in June and $63 \%$ in August while also increasing the percentage of $\mathrm{CP}$ and forage utilization when being grazed. Further research is needed on the establishment of legumes in NWSG in the mid-south United States before robust conclusions can be made on the economics of grazing NWSG with legumes. Additionally, research regarding $\mathrm{N}$ application to NWSG pastures may also be warranted to compare with NWSG pastures with legumes included.

The average cost/animal per grazing day was then compared with the average cost/animal per day using harvested feed rations in dairy heifer rearing. As noted before, the ADG by NWSG treatment was used to determine the ingredients for each ration that will theoretically produce the equivalent ADG over the same time period.

Table 5 presents the average cost per kilogram of gain for each of the theoretical harvested feed rations that achieve the same ADG as grazing each of the NWSG treatments. For each NWSG treatment, the average cost of gain per kilogram was highest for heifers fed corn silage with soybean meal. Corn silage with dry distillers grain had the lowest average cost of gain for rations developed to achieve similar ADG results as heifers grazing BBIG, SG, and $\mathrm{SG}+\mathrm{RC}$, and wet distillers grain ration had the lowest average cost of gain of the rations comparable to grazing $\mathrm{BBIG}+\mathrm{RC}$. The average cost of gain for harvested feed rations comparable to grazing $\mathrm{SG}$ and $\mathrm{SG}+\mathrm{RC}$ was higher than the average cost of gain for harvested feed rations with equivalent animal performance to heifers grazing $\mathrm{BBIG}$ and BBIG+RC. This was due to the marginal cost of gain (i.e., cost for an additional $\mathrm{kg}$ of gain) from harvested feed rations equivalent to $\mathrm{SG}$ and $\mathrm{SG}+\mathrm{RC}$ being higher than the marginal cost of gain for harvested feed rations equivalent to BBIG and BBIG+RC. This is likely explained by the amount of hay required in the harvested feed rations equivalent to grazing SG treatments and the cost of hay. Harvested feed rations that have the same animal performance as grazing SG and SG+RC had higher percentages of hay than for the rations that have the same animal performance as grazing BBIG and BBIG+RC. Feeding at a lower rate of gain resulted in higher percentages of hay in rations, leading to a higher average cost of gain for the rations comparable to grazing SG and $\mathrm{SG}+\mathrm{RC}$.

The use of NWSG in heifer rearing can be a costeffective method of growing dairy heifers. However, if the operation must use rations from harvested feeds, then it would be most cost effective to feed them on a higher plain of nutrition than what some NWSG provide. Though it is widely thought that roughages such as hay are most economical for feeding cattle, it is not always the case. Substituting harvested feeds become more economical as hay becomes scarce and hay price increases. Gadberry and Beck (2010) demonstrate where a corn price less than $\$ 0.15 / \mathrm{kg}$ makes corn a more cost-effective feed than grass hay at $\$ 73 / \mathrm{Mg}$. Thus, at certain times when harvested feeds are being fed, exceeding the nutrient levels provided by NWSG is more cost effective than only meeting the levels of nutrients supplied by grazing NWSG.

The average cost/animal per day was calculated under the 3 daily yardage and transportation fee scenarios (Table 5). On average, the cost of feeding the 3 rations, theoretically nutrient equivalent to grazing SG, ranged from $\$ 1.91 /$ animal/d (corn silage with dry distillers grains) to $\$ 2.72 / \mathrm{animal} / \mathrm{d}$ (corn silage with soybean meal). The cost of the feed rations equivalent to grazing $\mathrm{SG}+\mathrm{RC}$ was slightly lower than for $\mathrm{SG}$, and ranged from $\$ 1.89 / \mathrm{animal} / \mathrm{d}$ for corn silage with wet distillers grain to $\$ 2.69 / \mathrm{animal} / \mathrm{d}$ with corn silage and soybean meal. The cost of rations equivalent to grazing BBIG ranged from $\$ 2.02 /$ animal/d for corn silage with dry distillers grain to $\$ 2.89 / \mathrm{animal} / \mathrm{d}$ for corn silage with soybean meal, which was higher than the feed rations for $\mathrm{SG}$ and $\mathrm{SG}+\mathrm{RC}$. For BBIG+RC, the average cost/animal per day was higher than any other NWSG treatment, and ranged from $\$ 2.05 / \mathrm{animal} / \mathrm{d}$ for corn silage with wet distillers grain to $\$ 3.06 / \mathrm{animal} / \mathrm{d}$ for corn silage with soybean meal. All NWSG treatments had a lower average cost of grazing than all theoretically nu- 
trient equivalent harvested feed rations at all yardage fees. For example, the cost to feed the corn silage with dry distillers grains was $\$ 1.42, \$ 0.99, \$ 1.58$, and $\$ 1.27 /$ animal/d higher than grazing BBIG, BBIG+RC, SG, and $\mathrm{SG}+\mathrm{RC}$, respectively. A sensitivity analysis was conducted when all feedstuff prices were assumed to be reduced by $50 \%$ (Table 5). The results were similar to the average price scenario for all rations and NWSG.

Given the sensitivity analysis of daily yardage fees and transportation fees, it was more cost effective to rear dairy heifers through the summer by grazing them on NWSG rather than rearing them using harvested feed rations. The concept of grazing NWSG instead of feeding mechanically harvested feeds was similar to the cost savings experienced when stockpiling forages for winter feed and extending grazing seasons into the winter (Adams et al., 1994; Poore et al., 2000). This finding implies that dairy heifers can be reared during the summer months on NWSG at a lower cost than they can be reared on mechanically harvested feed rations and that NWSG can provide the nutrients necessary to meet $\mathrm{ADG}$ recommendations.

\section{CONCLUSIONS}

The average cost/animal per grazing day for SG was lower than the average cost/animal per grazing day for all other NWSG treatments evaluated in the study. Grazing SG was also found to have a lower average cost/animal per day than the average cost/animal per day of feeding 3 feed rations used in bred dairy heifer rearing, resulting in equivalent animal performance to grazing the NWSG treatments. Furthermore, rates of gain for SG were at a desirable level for heifer rearing. Therefore, grazing bred dairy heifers on SG during the summer months appears to be the most economically feasible feed for dairy heifer rearing to maximize average profits.

\section{REFERENCES}

Adams, D. C., R. T. Clark, S. A. Coady, J. B. Lamb, and M. K. Nielsen. 1994. Extended grazing systems for improving economic returns from Nebraska sandhills cow/calf operation. J. Range Manage. 47:258-263.

Biermacher, J. T., R. R. Reuter, M. K. Kering, J. K. Rogers, J. H Blanton Jr., J. A. Guretzky, and T. J. Butler. 2012. Expected economic potential for substituting legumes for nitrogen in bermudagrass pastures. Crop Sci. 52:1923-1930.

Blantchet, K. M., J. R. George, R. M. Gettle, D. R. Buxton, and K. J. Moore. 1995. Establishment and persistence of legumes interseeded into switchgrass. Agron. J. 87:935-941.

Bow, J. R., J. P. Muir, D. C. Weindorf, R. E. Rosiere, and T. J. Butler. 2008. Integration of cool-season legumes and dairy manure compost with switchgrass. Crop Sci. 48:1621-1628.

Boyer, C. N., R. K. Roberts, B. C. English, D. D. Tyler, J. A. Larson, and D. F. Mooney. 2013. Effects of soil type and landscape on yield and profit maximizing nitrogen rates for switchgrass production. Biomass Bioenergy 48:33-42.

Burns, J. C. 2011. Intake and digestibility among Caucasian bluestem, big bluestem, and switchgrass compared with bermudagrass. Crop Sci. 51:2262-2275.

Burns, J. C., D. S. Fisher, and K. R. Pond. 2011. Steer performance, intake, and digesta kinetics of switchgrass at three forage masses. Agron. J. 103:337-350.

Coblentz, W. K., P. C. Hoffman, N. M. Esser, and M. G. Bertram. 2012. Using eastern gamagrass to construct diets that limit intake and caloric density for dairy replacement heifers. J. Dairy Sci. 95:6057-6071

Doxon, E., P. D. Keyser, G. E. Bates, C. A. Harper, and J. Waller 2011. Economic implications of growing native warm-season grasses for forage in the mid-south. University of Tennessee Center for Native Grassland Management SP731-E. University of Tennessee, Knoxville.

Duffy, M. D. 2007. Estimated costs for production, storage, and transportation of switchgrass. Iowa State University Extension PM 2042. Iowa State University, Ames.

Gabler, M. T., P. R. Tozer, and A. J. Heinrichs. 2000. Development of a cost analysis spreadsheet for calculating the costs to raise a replacement dairy heifer. J. Dairy Sci. 83:1104-1109.

Gadberry, S., and P. Beck. 2010. Substituting grain for hay in beef cow diets. University of Arkansas Department of Animal Science FSA3036. University of Arkansas, Fayetteville.

Gillen, R. L., and W. A. Berg. 1998. Nitrogen fertilization of a native grass planting in western Oklahoma. J. Range Manage. 51:436441.

Griffith, A. P. 2012. Seasonal prices for feedstuffs commonly utilized in the Midsouth. University of Tennessee Extension W 296. University of Tennessee Institute of Agriculture.

Griffith, A. P., F. M. Epplin, S. D. Fuhlendorf, and R. Gillen. 2011 A comparison of perennial polycultures and monocultures for producing biomass for biorefinery feedstock. Agron. J. 103:617-627.

Haque, M., F. M. Epplin, and C. M. Taliaferro. 2009. Nitrogen and harvest frequency effect on yield and cost for four perennial grasses. Agron. J. 101:1463-1469.

Harsh, S., C. Wolf, and E. Wittenberg. 2001. Profitability and production efficiency of the crop and livestock enterprises of Michigan dairy operations: 1998 summary and analysis. Agricultural Economics Staff Paper No. 01-04. Michigan State University, East Lansing.

Heinrichs, A. J. 1993. Raising dairy replacements to meet the needs of the 21st century. J. Dairy Sci. 76:3179-3187.

Hopkins, B. A., and L. W. Whitlow. 2001. Feeding dairy heifers from weaning to calving. North Carolina State University Department of Animal Science ANS01-203D. North Carolina State University, Raleigh.

Howieson, J. G., G. W. O'Hara, and S. J. Carr. 2000. Changing roles for legumes in mediterranean agriculture: Developments from an australian perspective. Field Crops Res. 65:107-122.

Keyser, P. D., C. A. Harper, G. E. Bates, J. Waller, and E. Doxon. 2011. Native warm-season grasses for mid-south forage production. University of Tennessee Center for Native Grassland Management SP731-A. University of Tennessee, Knoxville.

Khanna, M., B. Dhungana, and J. Clifton-Brown. 2008. Costs of producing miscanthus and switchgrass for bioenergy in Illinois. Biomass Bioenergy 32:482-493.

Lardy, G. 2013. A cow-calf producer's guide to custom feeding. North Dakota State University Extension Center AS-1162, March.

Lowe, J. K., C. N. Boyer, A. P. Griffith, G. E. Bates, P. D. Keyser, J. C. Waller, J. A. Larson, and W. M. Backus. 2015. Profitability of beef and biomass production from native warm-season grasses in Tennessee. Agron. J. 107:1733-1740.

Mooney, D. F., R. K. Roberts, B. C. English, D. D. Tyler, and J. A. Larson. 2009. Yield and breakeven price of 'alamo' switchgrass for biofuels in Tennessee. Agron. J. 101:1234-1242.

Mott, G. O. 1960. Grazing pressure and the measurement of pasture production. Pages 606-611 in Proc. 8th Int. Grassland Congress. Alden Press, Oxford, UK. 
Olynk, N. J., and C. A. Wolf. 2010. Aligning incentives for contract dairy heifer growth. J. Agric. Res. Econ. 35:489-502.

Poore, M. H., G. A. Benson, M. E. Scott, and J. T. Green. 2000. Production and use of stockpiled fescue to reduce beef cattle production costs. J. Anim. Sci. 79:1-11.

Poppi, D. P., and S. R. McLennan. 1995. Protein and energy utilization by ruminants at pasture. J. Anim. Sci. 73:278-290.

University of Arkansas Division of Agriculture. 2006. Cattle grower ration balancing spreadsheet. Accessed Sep. 15, 2014. https://www. uaex.edu/farm-ranch/animals-forages/docs/Cattle\%20Grower\%20 Ration\%20Balancing\%20Spreadsheet\%20User\%20Guide.pdf.

University of Tennessee Department of Agricultural Economics. 2007. Ag Extension. Cool season grass/clover, no-till establishment. University of Tennessee, Ag Econ Budgets, Knoxville.

University of Tennessee Department of Agricultural Economics. 2009. $\mathrm{Ag}$ Extension. Guideline switchgrass establishment and annual production budgets over three year planning horizon. University of Tennessee, Ag Econ Budgets, Knoxville.
USDA. 2013. Livestock and grain market news portal. Accessed Sep. 15, 2014. https://www.marketnews.usda.gov/mnp/ls-reportconfig?category $=$ Hay.

US Department of Labor. 2013. Consumer price index history table, 1913 to present. US Department of Labor, Bureau of Statistics, Washington, DC. Accessed Sep. 15, 2014. http://www.bls.gov/cpi/ tables.htm.

USDA National Agricultural Statistics Service (USDA-NASS). 2013. Quick stats. Accessed Sep. 15, 2014. http://quickstats.nass.usda. gov/.

Wolf, C. A. 2003. Custom dairy heifer grower industry characteristics and contract terms. J. Dairy Sci. 86:3016-3022.

Zanton, G. I., and A. J. Heinrichs. 2007. The effects of controlled feeding of a high-forage or high- concentrate ration on heifer growth and first-lactation milk production. J. Dairy Sci. 90:3388-3396.

Zanton, G. I., and A. J. Heinrichs. 2008. Precision feeding dairy heifers: Strategies and recommendations. Penn State University Department of Animal Science DAS 2008-130. Penn State University. 